\title{
Acromegaly With Normal Basal Growth Hormone Levels
}

\author{
Gérard Mohr, Zhong-ping Chen and Morris Schweitzer
}

\begin{abstract}
Background: The most common cause of acromegaly is excess of growth hormone (GH) secretion. Methods: We report a 42-year-old male patient, who had become acromegalic over the past 5 years. There were no visual changes or change in sexual function, no gynaecomastia or galactorrhoea. Both CT and MRI scans showed a large mass measuring $2.5 \times 2.5 \times 3.5 \mathrm{~cm}$, originating from the sella turcica and extending into and totally filling up the sphenoid sinus with diffusely invasive features. Results: Basal serum GH level was within normal range, but insulin-like growth factor 1 (IGF-1) was elevated with slightly increased prolactin (PRL) and impaired GH secretory regulation as well. A pituitary adenoma was partially removed through transsphenoidal microsurgery. Pathology confirmed a mammo-somatotrophic adenoma but immunocytochemistry study of the tumour showed only positivity for PRL but not GH. Conclusions: When acromegaly occurs without GH level elevation, one should pay attention that: 1) IGF-1 might be the cause of the clinical feature of acromegaly; 2) The tumour might undergo morphological transformation; and 3) Hyperinsulinemia or GH receptor antibody formation could also be the cause of the acromegalic appearance.
\end{abstract}

RÉSUMÉ: Acromégalie avec niveau normal d'hormone de croissance: à propos d'un cas. Introduction: La cause la plus commune de l'acromégalie est l'excès de sécrétion d'hormone de croissance (GH). Méthodes: Nous rapportons le cas d'un patient de 42 ans qui était devenu acromégale depuis les cinq dernières années. Il n'y avait aucune modification de la vision ni des fonctions sexuelles, aucune gynécomastie ni galactorrhée. La tomodensitométrie et l'imagerie par résonnance magnétique (IRM) ont montré une volumineuse masse à caractères invasifs diffus, mesurant $2.5 \times 2.5 \times 3.5 \mathrm{~cm}$, prenant origine au niveau de la selle turcique et remplissant complètement le sinus sphénoïdal. Résultats: Le niveau sérique basal de GH était normal, mais le niveau du factor de croissance 1 de genre insulinique (IGF-1) était élevé avec une légère élévation de la prolactine (PRL) et une altération dans la régulation de la sécrétion de GH. Un adénome hypophysaire fut partiellement réséqué par microchirurgie transsphénoïdale. L'examen anatomopathologique a confirmé qu'il s'agiasait d'un adénome mammo-somatotrophe mais l'examen immunohistochimique de la tumeur n'a montré de positivité que pour la PRL, mais non pour la GH. Conclusions: Lorsqu'il y a symptômes d'acromégalie sans élévation de GH, on devrait se demander si: 1) l'IGF-1 peut être la cause des signes d'acromégalie; 2) la tumeur pourrait subir une transformation morphologique; et 3) une hyperinsulinémie ou la formation d'anticorps dirigés contre le récepteur GH pourraient être la cause des signes d'acromégalie.

Can. J. Neurol. Sci. 1997; 24: 250-253

Acromegaly was first recognized as a distinct clinical syndrome by Marie in $1886 .{ }^{1}$ The pituitary source of the disorder was confirmed in 1909 by Cushing. ${ }^{2}$ Now, it has been generally recognized as the result of an unrestrained secretion of growth hormone (GH) caused by several factors. ${ }^{3,4}$ To our knowledge, only few cases of acromegaly are reported to show normal serum GH levels but most of those patients were harbouring a GH secreting tumour. ${ }^{5-7}$ We present such an acromegaly case with normal basal serum GH level and immunocytochemistry negative for $\mathrm{GH}$ on tumour cells as well.

\section{Case Report}

This 42-year-old man noted a progressive increase in the size of his feet and hands over the past 5 years. His head became larger and as a result he could not find a baseball cap to fit his head. His jaw has been protruding out over the past 4 years. He did not complain of any unusual headaches, visual changes or change in sexual function and did not note any gynaecomastia or galactorrhoea. Physical examination: weight $121 \mathrm{~kg}$; blood pressure 140/90 $\mathrm{mmHg}$; optic fundi normal, visual acuity was $20 / 20$ in both eyes with normal visual fields. Presence of some frontal bossing, jaw protrusion and tongue enlargement; large, spade-like hands as well as large-wide feet (Figure 1).

From the Divisions of Neurosurgery, Endocrinology and Lady Davis Institute for Medical Research, Sir Mortimer B. Davis - Jewish General Hospital, McGill University, Montréal.

RECEIVED MARCH 5, 1996. ACCEPTED IN FINAL FORM FEBRUARY 25, 1997. Reprint requests to: Gérard Mohr, Chief, Division of Neurosurgery, Sir Mortimer B. Davis - Jewish General Hospital, 3755 Chemin de la Côte-Ste-Catherine, Montréal, Québec, Canada H3T 1E2 

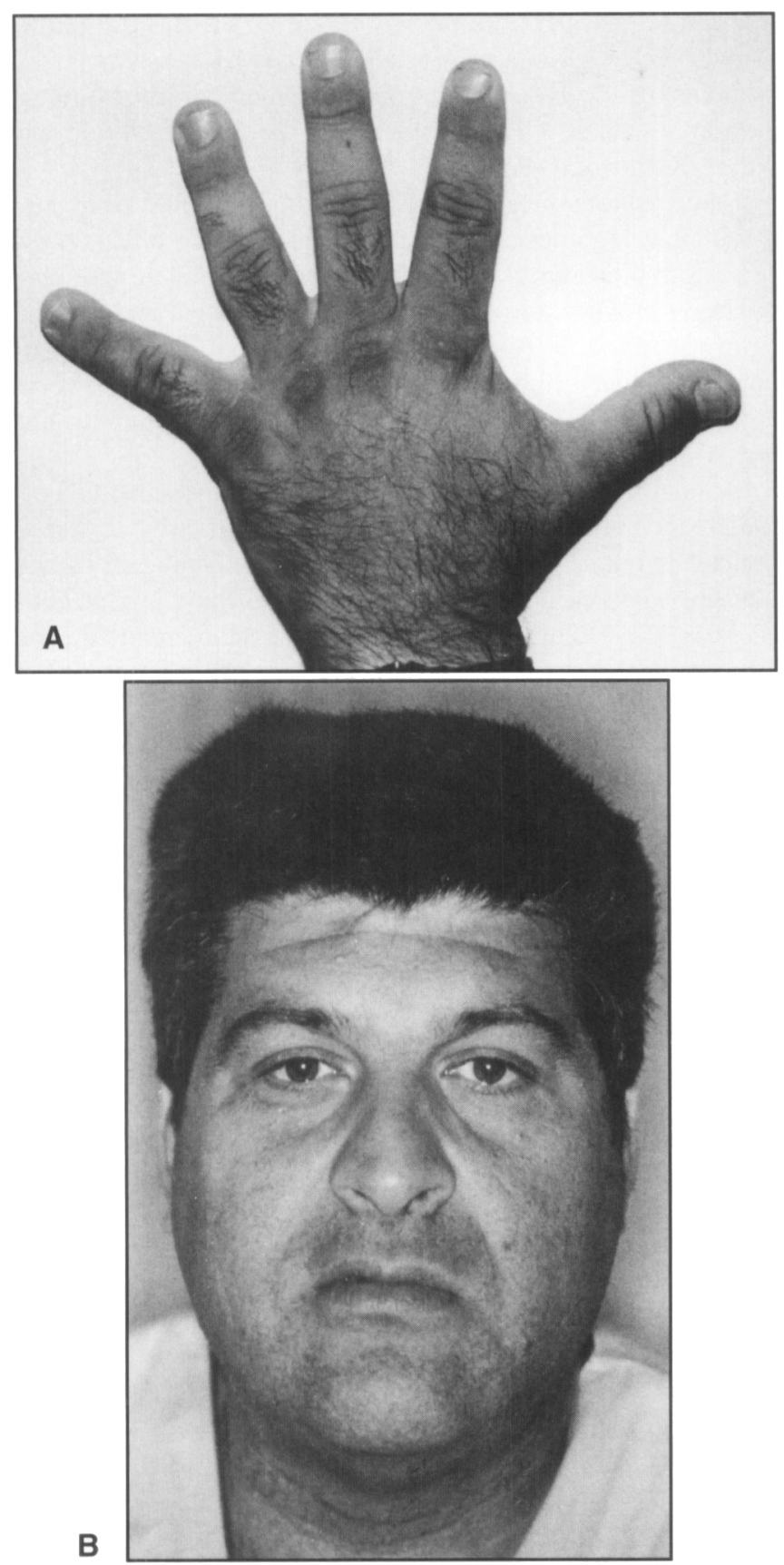

Figure 1: Acromegalic features of the patient.

Skull X-rays showed a demineralized sella. CT scan showed a large soft tissue mass originating from the sella turcica and extending into and totally filling the sphenoid sinus. There was only a slight amount of extension of the mass into the supersellar cistern without extrinsic compression of the optic chiasm (Figure 2). On MRI, this mass measured $2.5 \times 2.5 \times 3.5 \mathrm{~cm}$ and there was extension of the mass into the left cavernous sinus and invasion of part of the right cavernous sinus as well. Both carotid arteries were encased and wrapped by the tumour. These results were consistent with an invasive pituitary adenoma stage IV-A (Figure 3).

Laboratory tests demonstrated normal basal serum GH level, but increased insulin-like growth factor 1 (IGF-1; also called somatomedin C) with a slight PRL elevation (Table 1). TRH stimulation test for GH secretion was impaired (Table 2), while, oral glucose tolerance test (OGTT) for GH secretion was normal (Table 3).

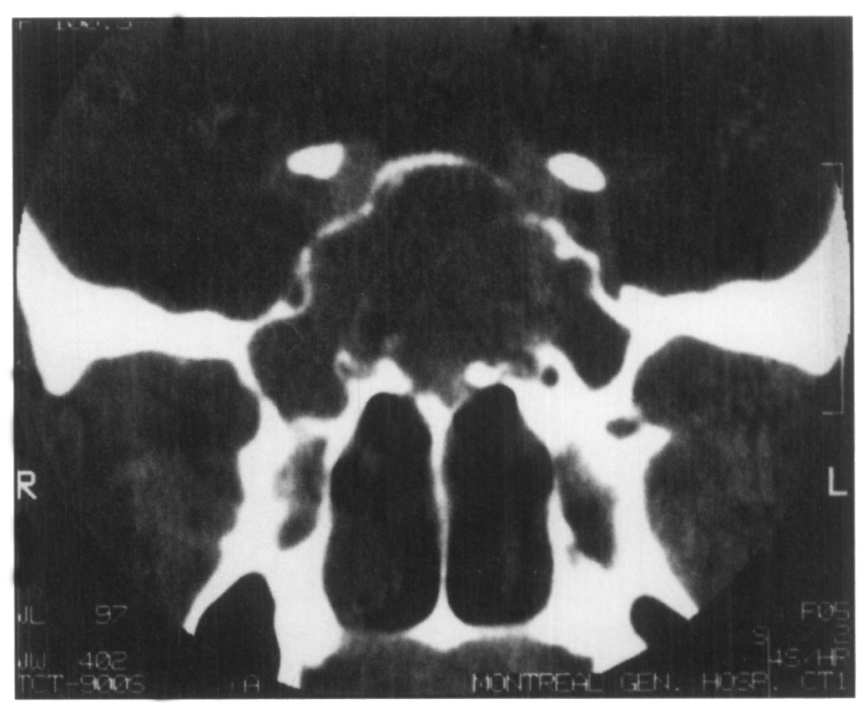

Figure 2: CT scan (coronal section) showing a pituitary tumour originating from the sella turcica, extending into and totally filling the sphenoid sinus.

Table 1: Basal Blood Hormone Levels.

\begin{tabular}{lll}
\hline Hormone & Baseline & Reference range \\
\hline $\mathrm{GH}^{\mathrm{a}}$ & $3.5 \pm 0.4 \mu \mathrm{g} / \mathrm{L}$ & $0.0-5.0 \mu \mathrm{g} / \mathrm{L}$ \\
Somatomedin C & $1.7 \mathrm{u} / \mathrm{ml}$ & $<1.0 \mathrm{u} / \mathrm{ml}$ \\
$\mathrm{PRL}$ & $26 \mu \mathrm{g} / \mathrm{L}$ & $0.0-15 \mu \mathrm{g} / \mathrm{L}$ \\
$\mathrm{FSH}$ & $4 \mathrm{u} / \mathrm{L}$ & $1-10 \mathrm{u} / \mathrm{L}$ \\
$\mathrm{LH}$ & $2 \mathrm{u} / \mathrm{L}$ & $2-12 \mathrm{u} / \mathrm{L}$ \\
Free Testosterone & $32.1 \mathrm{pmol} / \mathrm{L}$ & $28.0-156.0 \mathrm{pmol} / \mathrm{L}$ \\
Cortisol & $245 \mathrm{mmol} / \mathrm{L}$ & $140-690 \mathrm{mmol} / \mathrm{L}$ \\
\hline
\end{tabular}

${ }^{a}$ mean $\pm \mathrm{SE}$ of results from two separate moming fasting blood samples.

Table 2: TRH Stimulation Test.

\begin{tabular}{lll}
\hline No. & Time & GH levels $(\mu \mathrm{g} / \mathrm{L})$ \\
\hline 1 & 0 & 3.9 \\
2 & $15 \mathrm{~min}$ & 4.1 \\
3 & $30 \mathrm{~min}$ & 3.6 \\
4 & $60 \mathrm{~min}$ & 4.4 \\
\hline
\end{tabular}

Table 3: Oral Glucose Tolerance Test.

\begin{tabular}{lccc}
\hline No. & Time & GH levels $(\boldsymbol{\mu g} / \mathbf{L})$ & Glucose levels $(\mathbf{m m o l} / \mathbf{L})$ \\
\hline 1 & 0 & 3.3 & 4.9 \\
2 & $30 \mathrm{~min}$ & 3.0 & 7.7 \\
3 & 1 hour & 3.3 & 6.8 \\
4 & $2 \mathrm{hrs}$ & 2.8 & 5.0 \\
5 & $3 \mathrm{hrs}$ & 3.6 & 3.3 \\
6 & $4 \mathrm{hrs}$ & 3.0 & 4.4 \\
7 & $5 \mathrm{hrs}$ & 3.3 & 5.1 \\
\hline
\end{tabular}

A transsphenoidal approach was chosen to debulk the tumour. The specimen was examined under light microscope with routine haematoxylin-eosin (HE) stain. The tumour consisted of sheets of cells with poorly defined cytoplasm, which seemed to be devoid of cytoplasmic granules and had large nucleoles as well as frequent mitoses. Some cells appeared to contain a paranuclear cytoplasmic hyaline inclusion or socalled "fibrous bodies". In some areas of the surrounding bone, infiltration by tumour cells could be seen. Immunoperoxidase against human GH, PRL, ACTH, TSH, FSH and LH showed positivity only for PRL 

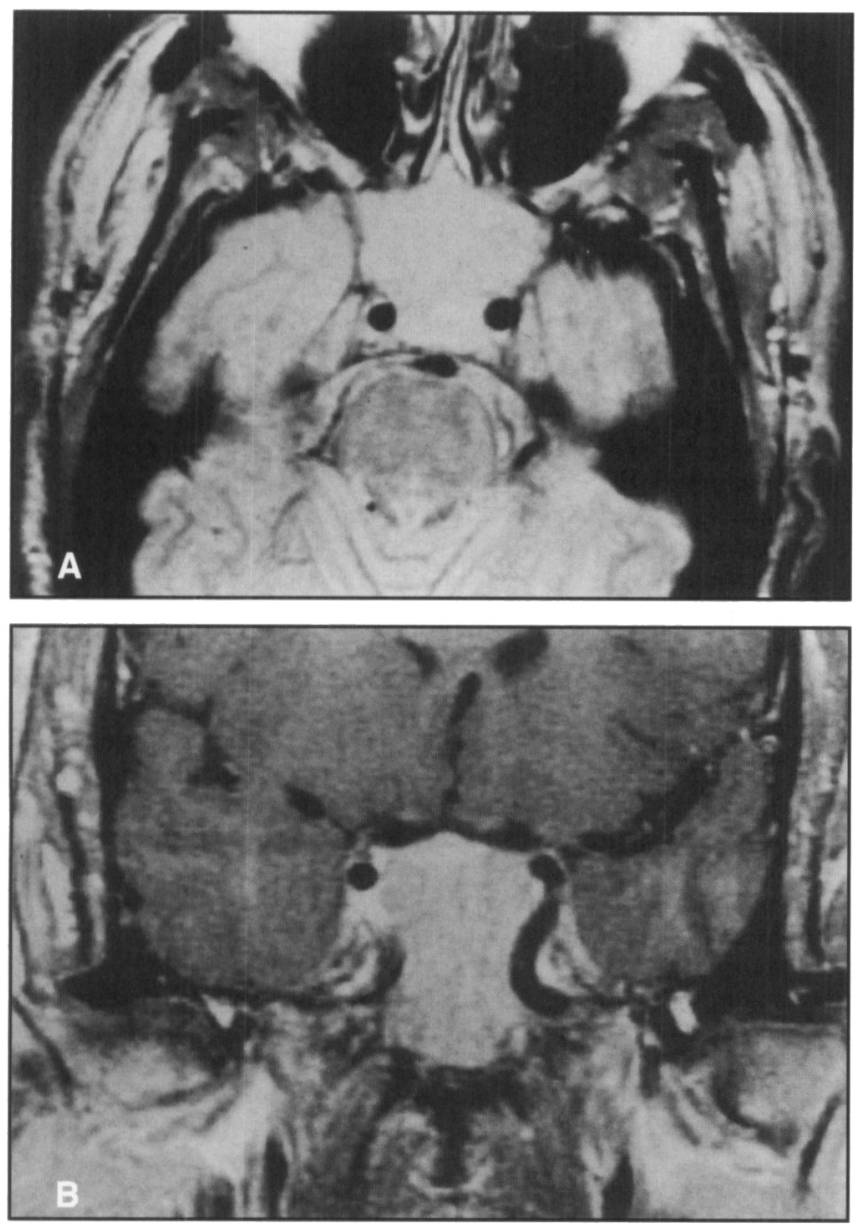

Figure 3: $M R I$ (A: axial section; $\boldsymbol{B}$ : coronal section) showing mass measuring $2.5 \times 2.5 \times 3.5 \mathrm{~cm}$ with extension into the left cavernous sinus as well as invasion of part of the right cavernous sinus. Both carotid arteries are encased and wrapped by the tumour consistent with an invasive pituitary adenoma stage $I V-A$.

consistent with a mammosomatotropic adenoma. Electron microscopic examination showed the cells attached one to another by well-defined junctional complexes containing scarce granules found only at the periphery of the cell along the cytoplasmic membrane. They were small, measuring less than $200 \mathrm{~nm}$. Although electron microscopic study favours the diagnosis of nonfunctional adenoma (might be sampling problem), the presence of fibrous bodies on light microscopy still prefers the presence of a somatotropic or mammosomatotropic adenoma.

One month after operation, patient was treated by conventional radiotherapy with total doses of $5040 \mathrm{cGy}$ in 28 fractions, and recovered well. Three months later, he developed a C.S.F. leakage and meningitis, which were eventually cured through transsphenoidal packing with fascia and muscles.

\section{DISCUSSION}

The clinical features of acromegaly are primarily due to excess growth hormone or growth factor secretion. Melmed ${ }^{4}$ has classified hypersomatotropism as: 1) Pituitary acromegaly, 2) Acromegaloidism, 3) Ectopic GH secretion, 4) Eutopic hypothalamic growth hormone - releasing hormone - secreting tumour, 5) Ectopic growth hormone - releasing hormone secreting tumour. Among these, acromegaloidism refers to patients with acromegalic features with normal serum levels of GH and IGF-1 and no evidence of pituitary or extrapituitary tumour. Those patients may produce an erythroprogenitor growth factor. ${ }^{8}$ Sometimes, pachydermoperiostosis may also mimic acromegaloidism. ${ }^{9}$ Our patient had a confirmed pituitary adenoma, with no GH elevation. Why did acromegaly develop without $\mathrm{GH}$ excess secretion?

Some authors found that immunoradioassay (RIA) may have a so-called high-dose "hook effect", or prozone effect, where extremely high serum concentrations of an antigen may paradoxically produce a lower response than expected and, on dilution, produce a higher assay response. ${ }^{10}$ But immunocytochemistry study of the tumour specimen did not reveal any GH positive cells, which would exclude the missing high $\mathrm{GH}$ levels in our case.

Animal models of hypersomatotropism suggest that $\mathrm{GH}$ and IGF-1 act both independently and synergistically to induce skeletal and organ growth. Growth hormone may directly stimulate the early differentiation of prechondrocyte stem cells, whereas IGF-1 may induce replication of the committed chondrocytes. " The elevated level of IGF-1 in this patient may be the major cause of acromegaly.

Many authors agree that prolactin also has somatotropic activities, as it belongs to the so-called PRL-GH family with similar structural features. ${ }^{13,14}$ Hyperprolactinemia is found in $25 \%$ to $65 \%$ of acromegalic patients and may arise through two possible mechanisms: anatomic or functional hypothalamicpituitary disconnection inhibiting PRL inhibitory factors on the pituitary gland and overproduction of both GH and PRL by adenomas. ${ }^{15}$ Furuhata et al. analyzed 22 consecutive cases of adenomas in acromegalic patients and found that all the tumours contained prolactin-reactive cells. They proposed that there may be no pure GH cell adenoma. ${ }^{15,16}$ Lloyd et al. consider that there may be a common precursor cell for GH and PRL and have speculated on the origin of pituitary adenomas in acromegalic patients from precursor cells. Some fetal somatotroph cells may differentiate into mammosomatotroph cells and then into the mammototroph cells. ${ }^{17}$ This may be applicable to the cell differentiation of pituitary adenomas and may account for some cases of acromegaly without GH elevation but increased PRL. As in this case, the patient could originally have a GH secreting adenoma, while 5 years later when he came to be treated, the tumour had transformed to mammototrophic adenoma, so that we could only find PRL elevation but no GH.

It has also been noticed in some insulin resistant patients that hyperinsulinemia may result in pseudoacromegaly. ${ }^{7,18,19} \mathrm{High}$ levels of insulin may also be acting through IGF-1 receptors, further promoting the acromegaloid phenotype. Patients usually do not have hypoglycemia, because of a molecular lesion involving an intermediate signal required for both insulin and IGF-1 regulation of glucose transport, and/or an effector mechanism operative in this process. Although there was no clinical evidence of hyperinsulinemia, unfortunately, we did not measure insulin levels in this patient.

Rarely, growth hormone receptor antibodies may also have GH-like activity. ${ }^{20,21}$ It is currently known that the GH receptor antibodies are most likely so called "Big-Big" GH. But, in that case, the patient must have an active GH secreting tumour, even though the serum GH levels may be normal. In this patient, there was no evidence of GH secretion on immunocytochemistry study of the tumour specimen, excluding it as the cause of acromegaly. 


\section{REFERENCES}

1. Marie P. Sur deux cas d'acromégalie: hypertrophie singulière non congénitale des extrémités supérieures, inférieures et céphalique. Rev Med 1886; 297-333.

2. Cushing H. Partial hypophysectomy for acromegaly: with remarks on the function of the hypophysis. Ann Surg 1909; 50: 10021017.

3. Melmed S, Braunstein GD, Horvath E, Ezrin C, Kovacs K. Pathophysiology of acromegaly. Endocr Rev 1983; 4: 271-290.

4. Melmed S. Acromegaly. N Engl J Med 1990; 5: 966-977.

5. Mims RB, Bethune JE. Acromegaly with normal fasting growth hormone concentrations but abnormal growth hormone regulation. Ann Intern Med 1974; 81: 781-784.

6. Brockmeier SJ, Buchfelder M, Adams EF, Schott W, Fahlbusch R. Acromegaly with "normal" serum growth hormone levels: clinical features, diagnosis and results of transsphenoidal microsurgery. Horm Metab Res 1992; 24: 392-396.

7. Flier JS, Moller DE, Moses AC, et al. Insulin-mediated pseudoacromegaly: clinical and biochemical characterization of a syndrome of selective insulin resistance. J Clin Endocrinol Metab 1993; 76: 1533-1541.

8. Ashcraft MW, Hartzband PI, Van Herle AJ, Bersch N, Golde DW. A unique growth factor in patients with acromegaloidism. J Clin Endocrinol Metab 1983; 57: 272-276.

9. Mahy IR, Wiggins J. Pachydermoperiotosis mimicking acromegaly. J R S Med 1992; 85: 46-47.

10. Comtois R, Robert F, Hardy J. Immunoradiometric assays may miss high prolactin levels. Ann Intern Med 1993; 119: 173.

11. Mathews LS, Hammer RE, Behringer RR, et al. Growth enhancement of transgenic mice expressing human insulin-like growth factor I. Endocrinology 1988; 123: 2827-2833.
12. Pagesy PJ, LI Y, Rentier-Delrue F, et al. Growth hormone and somatostatin gene expression in pituitary adenomas with active acromegaly and minimal plasma growth hormone elevation. Acta Endocrinol 1990; 122: 745-752.

13. Nicoll CS. Prolactin and growth hormone: specialists on one hand and mutual mimic on the other. Perspect Biol Med 1982; 25: 369-381.

14. Ferreira MF, Pires JS, Sobrinho LG. Prolactin, weight gain and psychgeny. In: S. Melmed, ed. Molecular and Clinical Advances in Pituitary Disorders: Proceedings of the 3rd International Pituitary Congress. Endocrine Research and Education, INC. 1993: 243-248.

15. Furuhata $S$, Kameya T, Otani M, Toya $S$. Prolactin presents in all pituitary tumours of acromegalic patients. Hum Pathol 1993; 24: 10-15.

16. Lloyd RV, Can M, Chandler WF, et al. Human growth hormone and prolactin secreting pituitary adenomas analyzed by in situ hybridization. Am J Pathol 1989; 134: 605-613.

17. Baker BL, Jaffe RB. The genesis of cell types in the adenohypophysis of the human fetus as observed with immunocytochemistry. Am J Anat 1975; 143: 137-162.

18. Joseph D'ercole A, Underwood LE, Groelke J, Plet A. Leprechaunism: studies of the relationship among hyperinsulinism, insulin resistance and growth retardation. J Clin Endocrinol Metab 1979; 48: 495-502.

19. Moller DE, Flier JS. Insulin resistance: mechanisms, syndromes and implications. N Engl J Med 1991; 325; 938-948.

20. Campino C, Szecowka J, Lopez JM, Mulchahey J, Seron-Ferre M. Growth hormone $(\mathrm{GH})$ receptor antibodies with GH-like activity occur spontaneously in acromegaly. J Clin Endocrinol Metab 1992; 74: 751-756.

21. Stolar MW, Amburn K, Baumann G. Plasma "big" and "big-big" growth hormone $(\mathrm{GH})$ in man: an oligomeric series composed of structurally diverse GH monomers. J Clin Endocrinol Metab 1984; 59: 212-218. 